\title{
EFFICIENT ENERGY MANAGEMENT SYSTEM AT KUWAIT OIL COMPANY, KUWAIT, A CASE STUDY
}

\author{
ENG. YOUSEF E. AL-QALLAF, ENG. FATIMA OWAYED \& ENG. PARISUDDA RAO \\ Health \& Environment Team, KOC, Kuwait.
}

\begin{abstract}
Effective energy management involves making decisions that lead to the conservation of energy and the efficient use of resources for sustainable future. Kuwait Oil Company (KOC), a subsidiary of Kuwait Petroleum Corporation (KPC), is involved in exploration, drilling and production of oil and gas. KOC is fully committed towards energy management, energy efficiency and greenhouse gases (GHGs) emissions reduction, which may help in minimizing energy costs and mitigating environmental effects. In order to meet national and international standards ISO 50001 Energy Management System (EnMS), KOC undertaken a pilot study for developing an effective energy management program for KOC representative process units and main buildings. The objective of the program was to create an energy baseline and identify the potential improvement areas and provide inputs for the implementation of ISO 50001 for certification. KOC has established the Energy Performance Indicators (EnPIs) for each of the process units and specific KPIs has been identified to monitor and control the energy performance. Furthermore, the study highlights the major achievements towards energy management, energy efficiency and greenhouse gas (GHGs) emissions reduction in order to help in minimizing energy costs and mitigating environmental effects.
\end{abstract}

Key Words: energy baseline, energy cost \& energy saving best practices, EnPIs, ISO EnMS.

\section{INTRODUCTION}

The systemic waste of natural resources in the Gulf is eroding economic resilience to shocks and increasing security risks. The six Gulf Cooperation Council (GCC) countries now consume more primary energy than the whole of Africa. Almost 100\% of energy is produced from oil and gas without carbon dioxide abatement. If the region's fuel demand were to continue rising as it has over the last decade, it would double by 2024 .

This is a deeply undesirable prospect for both the national security of each state and the global environment. KOC was established in 1934, is one of the largest oil exporter in the world, headquartered in Ahmadi, Kuwait. The Company activities had extended to include exploration operations, on-shore and offshore surveys, drilling of test wells, and developing of producing fields in addition to crude and natural gas exploration.

KOC undertaken a pilot study consisting of three process units and two main buildings. The task was to create an energy baseline \& identify the potential energy saving opportunities.

All energy sources have been considered in the study and wherever the data was available have been analyzed for performance and the opportunities in the five selected pilot sites. They have conducted a detailed study after site visits and interactions with the process owners and identified the potential areas for improvement with recommendation. The selected pilot sites are mentioned below [1].

- Gathering Center (GC-04)

- Booster Station (BS-160)

- Effluent Water Disposable Plant (EWDP - II)

- KOC Main Office Building

- KOC New Office Complex Building (B1) 
The program was developed in accordance with national and internal standards ISO 50001:2011 Energy Management System (EnMS) Requirements [2]. KOC has already appointed a Management Representative, Core energy management team to guide and take forward the energy improvement activities. Energy Policy has been defined. Training on ISO 50001 awareness has been provided to the employees \& contractors.

\section{METHODOLOGY}

\section{COMPLIANCE TO LEGAL \& OTHER REQUIREMENTS}

The study was comply with national and international regulations on energy conservation code for buildings [3]. Further, the State of Kuwait State of Kuwait is a signatory to COP\#21 wherein it has committed to reduce the impact on environment by reducing the greenhouse gases [4]. To achieve this KOC has to reduce its burning of fossil fuel.

\section{BASELINE}

Based on the data made available, the baseline for all the five pilot sites have been made and analyzed. The data period has been considered from Oct'2013 to Mar'2015 (18 months period). The Target for each site has been derived using the six-sigma concept considering a confidence level of 70\%. Energy Conservation Plan that has been identified [5] is addressed in the Energy savings and cost effective opportunities.

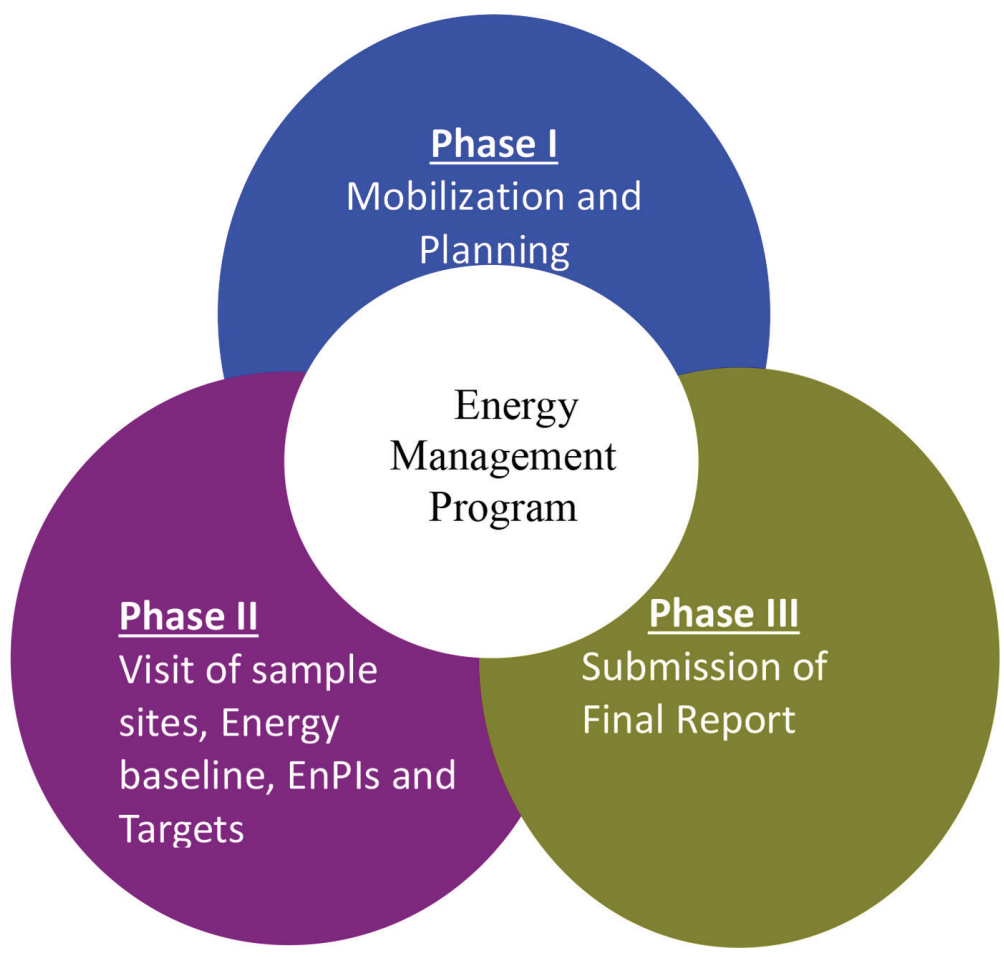

Figure 1: Different Phases for Energy Management Program. 
Table 1: Baseline Data Including Energy Performance Indicators (EnPIs)

\begin{tabular}{|c|c|c|c|c|c|}
\hline \multirow{3}{*}{$\frac{\text { S.No }}{1}$} & \multirow{3}{*}{$\begin{array}{l}\text { Pilot Site } \\
\text { GC } 04\end{array}$} & \multirow{2}{*}{\multicolumn{2}{|c|}{$\frac{\text { Baseline }}{\text { (Oct'13 - Mar'15) }}$}} & \multirow{3}{*}{$\begin{array}{l}\text { EnPI } \\
\mathrm{kWh} / \mathrm{MBOE}\end{array}$} & \multirow{3}{*}{$\frac{\frac{\text { Estimated }}{\text { Energy Savings \% }}}{\mathbf{1 5 . 2}}$} \\
\hline & & & & & \\
\hline & & \multirow{3}{*}{$\begin{array}{l}\text { Electrical } \\
\text { Thermal } \\
\text { Overall energy } \\
\text { Equivalent }\end{array}$} & 613.5 & & \\
\hline & & & 12934.5 & $\mathrm{SCF} / \mathrm{MBOE}$ & 7.0 \\
\hline & & & 3684 & $\mathrm{MkCal} / \mathrm{MBOE}$ & 7.7 \\
\hline \multirow[t]{3}{*}{2} & \multirow[t]{3}{*}{ BS 160} & Electrical & 1118.7 & $\mathrm{kWh} / \mathrm{MBOE}$ & 20.7 \\
\hline & & Thermal & 4037.4 & MSCF/MBOE & 3.5 \\
\hline & & $\begin{array}{l}\text { Overall energy } \\
\text { Equivalent }\end{array}$ & 986.1 & MMkCal/MBOE & 3.5 \\
\hline \multirow[t]{3}{*}{3} & \multirow[t]{3}{*}{ EWDP II } & Electrical & 0.413 & $\mathrm{kWh} / \mathrm{BBLS}$ & 5.7 \\
\hline & & Thermal & 0.501 & SCF/BBLS & 10.8 \\
\hline & & $\begin{array}{l}\text { Overall energy } \\
\text { Equivalent }\end{array}$ & 0.477 & MkCal/BBLS & 4.2 \\
\hline \multirow[t]{2}{*}{4} & Main Office & Winter & 2.47 & $\mathrm{kWh} / \mathrm{m}^{2} /$ day & 4.98 \\
\hline & Building & Summer & 2.90 & $\mathrm{kWh} / \mathrm{m}^{2} /$ day & 6.25 \\
\hline \multirow[t]{2}{*}{5} & New Office & Winter & 0.39 & $\mathrm{kWh} / \mathrm{m}^{2} /$ day & 11.1 \\
\hline & Complex & Summer & 1.09 & $\mathrm{kWh} / \mathrm{m}^{2} /$ day & 12.3 \\
\hline
\end{tabular}

\subsection{Identification of areas of Significant Energy Use (GC-04)}

Significant energy use refers to energy use accounting for substantial energy consumption and/or offering considerable potential for energy performance improvement. In line with this, significant energy use equipment/processes were identified based on the electrical load data furnished for GC-04. The share of total connected load of equipment \& machineries, which are presently operated are depicted below to understand and highlight the significant power consumers [6].

\subsection{Identification of areas of Significant Energy Use (BS-160)}

Significant energy use refers to energy use accounting for substantial energy consumption and/or offering considerable potential for energy performance improvement. In line with this, significant energy use equipment/processes were identified based on the electrical load data furnished for BS - 160 [7]. The share of total energy use is evolved to understand the contribution of thermal energy (fuel gas) and electrical energy in the day-to-day operations of BS 160 is depicted in figure below.

\subsection{Identification of areas of Significant Energy Use (EWDP-II)}

The thermal energy is used only in sludge separators and rest of other systems utilizes electrical energy and majority of them are motor driven equipment. The share of total connected 


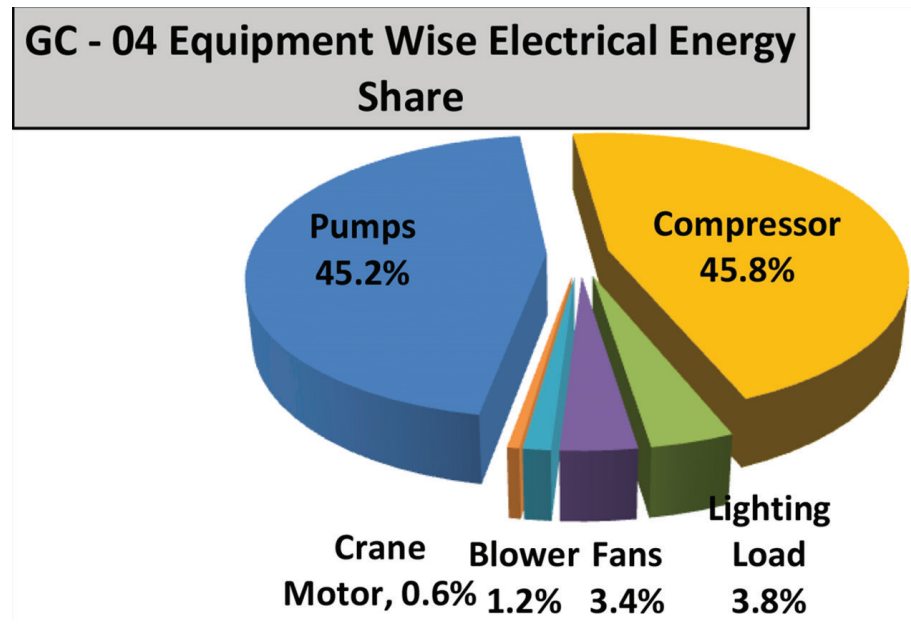

Figure 2: Significant Energy Consumption for GC-04.

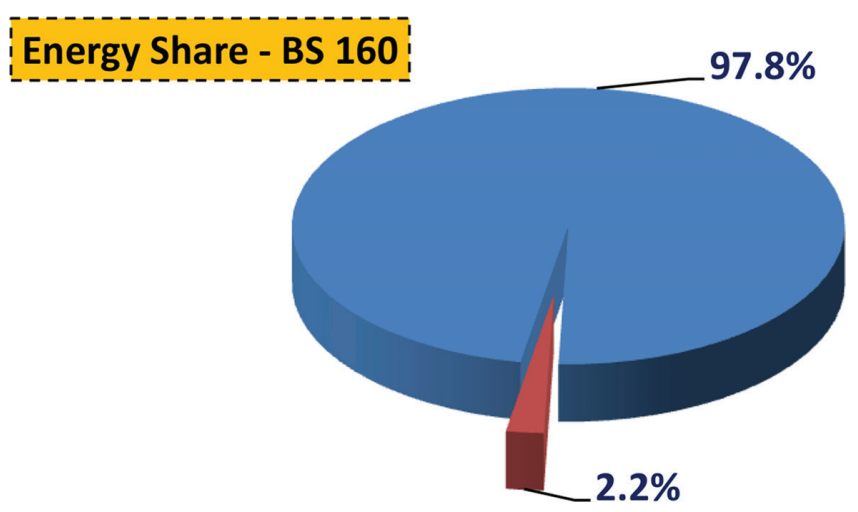

Figure 3: Significant Energy Consumption for BS-160.

load of equipment \& machineries, which are presently operated are depicted to understand and highlight the significant power guzzlers.

\subsection{Identification of areas of Significant Energy Use (Main Office Building)}

Significant energy use equipment/processes were identified based on the electrical load data furnished for main office building. The share of total connected load of electrical equipment $\&$ machineries.

\subsection{Identification of areas of Significant Energy Use (New Office Complex)}

The major variables affecting the energy use for new office complex has identified based on observations, analysis and understanding of process operations and energy utilization [8]. 


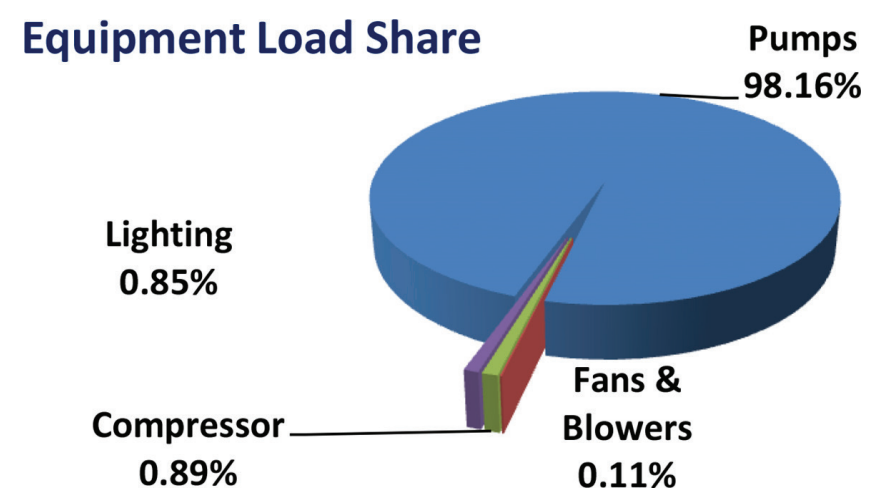

Figure 4: Significant Energy Consumption for EWDP-II.

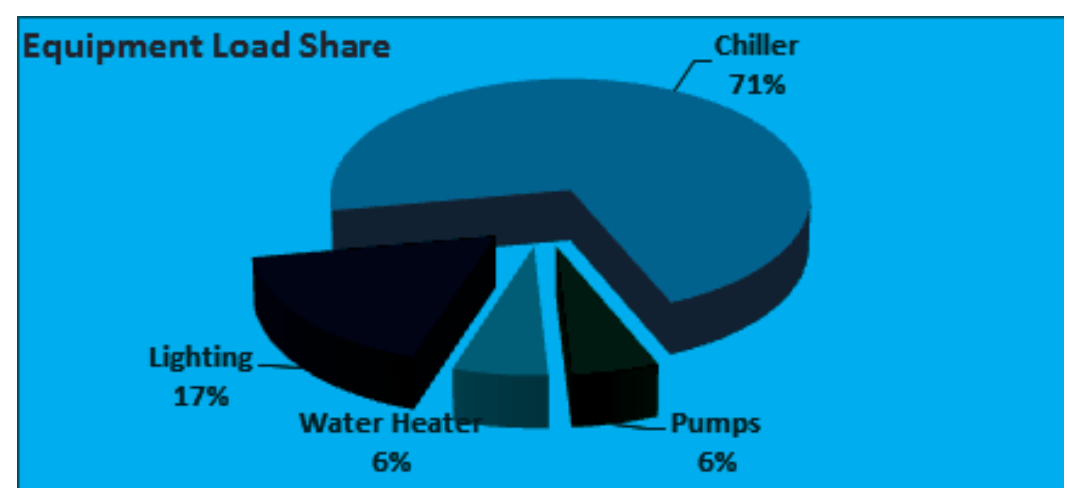

Figure 5: Significant Energy Consumption for Main Office Building.

Electricity Consumption Vs Temperture

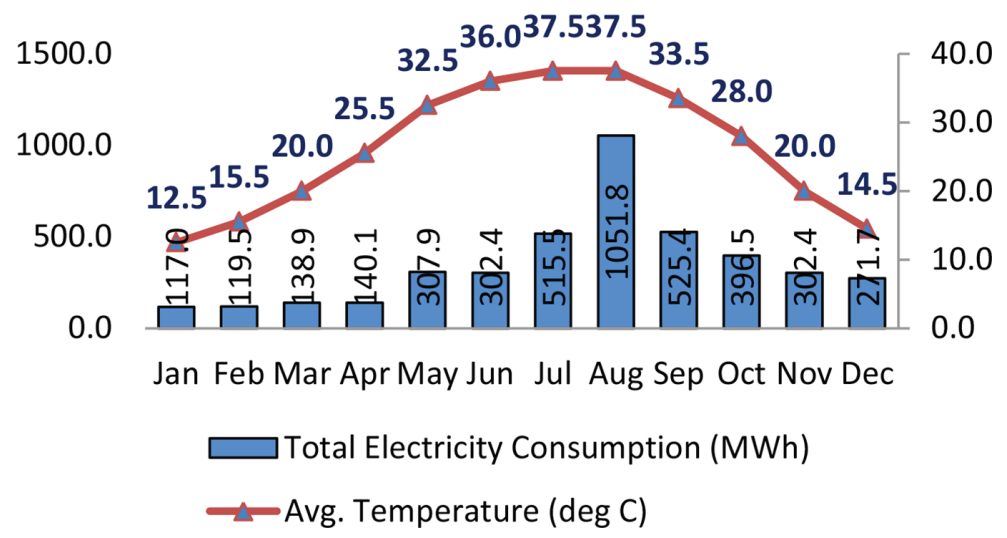

Figure 6: Significant Energy Consumption Vs Temperature at New Office Complex. 
Further the trend for electricity consumption vs ambient temperature is evolved for the baseline period to visualize the impact of climatic variations on electricity as depicted in the below [9].

\section{ENERGY SAVING OPPORTUNITIES}

The site-specific observations comprises identification of significant energy use discussed above and existing \& identified energy savings opportunities are summarized for all five pilot sites in below table [10].

\section{CONCLUSION}

The company should creating baseline for other process units, in order to monitor and verify the energy performance. Further, metering \& sub metering system for electrical and thermal where

Table 2: Existing and Identified Energy Saving Opportunities

\begin{tabular}{|c|c|c|c|}
\hline S.No & Pilot Site & $\begin{array}{l}\text { Existing Energy Savings } \\
\text { Opportunities }\end{array}$ & Identified Energy Saving Opportunities \\
\hline 1 & GC 04 & $\begin{array}{l}\text { Running Gas engine/turbine } \\
\text { for Tank Vapor compressors } \\
\text { instead of motors }\end{array}$ & $\begin{array}{l}\text { 1. Review and optimize the sizing of } \\
\text { Pumps and loading and unloading } \\
\text { of compressors. }\end{array}$ \\
\hline 2 & BS 160 & $\begin{array}{l}\text { Utilization of Energy Efficient } \\
\text { Gas Turbine in gas compres- } \\
\text { sion process }\end{array}$ & $\begin{array}{l}\text { 2. Installing VFD based on Process } \\
\text { demands. } \\
\text { 3. Rectify Leakages of utilities. }\end{array}$ \\
\hline 3 & EWDP II & $\begin{array}{l}\text { Use of metering \& monitoring } \\
\text { mechanisms for the electrical } \\
\text { equipment }\end{array}$ & $\begin{array}{l}\text { 4. Monitoring use of Energy with } \\
\text { Meters } \\
\text { 5. Optimizing loading on motors. } \\
\text { 6. Monitor Carbon and water foot } \\
\text { print in all process areas } \\
\text { 7. Optimize transformer losses } \\
\text { 8. Use LED instead of conventional } \\
\text { lamps } \\
\text { 9. HVAC usage and control }\end{array}$ \\
\hline 4 & $\begin{array}{l}\text { Main } \\
\text { Office } \\
\text { Building }\end{array}$ & $\begin{array}{l}\text { 1. LED Replacement } \\
\text { 2. Switching off office loads } \\
\text { (computers, lights, AC units }\end{array}$ & $\begin{array}{l}\text { 1. Insulate all cold lines and vessels } \\
\text { 2. Optimize Insulation thickness and } \\
\text { material }\end{array}$ \\
\hline 5 & $\begin{array}{l}\text { New } \\
\text { Office } \\
\text { Complex }\end{array}$ & $\begin{array}{l}\text { etc.) When office is not } \\
\text { occupied. } \\
\text { 3. VFD pump sets are } \\
\text { installed to modulate } \\
\text { chilled water flow. } \\
\text { 4. Water saving devices are } \\
\text { installed on all taps. }\end{array}$ & $\begin{array}{l}\text { 3. Optomize air volumes with false } \\
\text { ceiling and segregation of areas } \\
\text { 4. Usage of Air curtains } \\
\text { 5. Minimize roof heating loads with } \\
\text { roof cooling and roof painting } \\
\text { 6. Precooling of fresh air with air to } \\
\text { air heat exchangers } \\
\text { 7. Optimize thermostat settings } \\
\text { 8. Regular maintenance of A/C and } \\
\text { Refrigeration } \\
\text { 9. Minimize part load operations }\end{array}$ \\
\hline
\end{tabular}


not available, be provided on priority. (Energy meters and Flow meters). A comprehensive investment grade energy audit (IGA) should be conducted to for each process site and buildings for capturing the individual equipment performance and identify the losses and pin point energy conservation opportunities and also Carry out Testing, Adjusting and Balancing (TAB) for the HVAC system for the buildings to improve the chiller efficiency and performance.

Additionally, increase the use of renewable and clean energy technologies such as Solar PV in office buildings (use of Solar PV for lighting load in main \& new office buildings to replace the conventional power source), Solar Thermal technologies in process heating and use of LNG instead of fossil fuel based electricity. For the Green building concept, KOC needs to get certified to ISO 50001 and then follow the LEED reference guide for Building Design \& Construction v4 [11].

\section{ABBREVATIONS}

KOC - Kuwait Oil Company

KPC - Kuwait Petroleum Corporation

GHGs - Greenhouse Gases

EnMS - Energy Management System

COP - Conference of Parties

GC- Gathering Center

BS - Booster Station

EWDP - Effluent Water Disposal Plant

EnPI - Energy Performance Indicator

GCC - Gulf Cooperation Council

LED - Light-Emitting Diode

VFD - Variable Frequency Drive

IGA - Investment Grade Energy Audit

HVAC - Heating Ventilation Air Conditioning System

TAB - Testing, Adjusting and Balancing

LNG - Liquefied Natural Gas

LEED - Leadership in Energy and Environmental Design

\section{REFERENCES}

[1] A Study on Energy Management Program in KOC.

[2] ISO 50001:2011 Energy Management System (EnMS).

[3] Related Standards and Guidelines on Energy Conservation Code in Buildings by (Ministry of Energy (MoE), Kuwait

[4] State of Kuwait State of Kuwait is a signatory to COP\#21 wherein it has committed to reduce the impact on environment by reducing the GHG emissions.

[5] Energy Conservation \& Demand Management Plan 2014 - 2019 Technical Report OAKVILLE.

[6] Energy Efficiency Reference for Environmental Reviewers, March 2010 - EPA Publication No. 315-R-09-001.

[7] Bhattacharyya, S.C., Energy data and energy balance. Energy Economics, SpringerVerlag, London, 2011. https://doi.org/10.1007/978-0-85729-268-1_2 
[8] Kaneda, D., Jacobson, B. \& Rumsey, P., Plug oad Reduction: The Next Big Hurdle for Net Zero Energy Building Design. ACEEE Summer Study on Energy Efficiency in Buildings; 2010.

[9] Menezes, A., Cripps, A., Bouchlaghem, D. \& Buswell, R., Analysis of electricity consumption for lighting and small power in office buildings, CIBSE Technical Symposium, 6th-7th September, DeMontfort University, Leicester, UK, 2011.

[10] IPIECA, Climate Change 2013 - "Saving energy in the oil and gas industry", 2013. Available at: www.ipieca.org

[11] Available at: http://www.usgbc.org/leed 